\title{
Resistance of Bacillus larvae in beeswax
}

\author{
M Máchová \\ Bee Research Institute, Dol 25266 Libčice nad Vitavou, Czech Republic
}

(Received 20 January 1992; accepted 12 October 1992)

\begin{abstract}
Summary - A simple routine microbiological method was used to determine the titre of viable Bacillus larvae spores in beeswax. Viable bacillus larvae spores in beeswax were tested for heat resistance at the constant temperature of $150{ }^{\circ} \mathrm{C}$ and for acid-resistance to $0.5 \% \mathrm{H}_{2} \mathrm{SO}_{4}$. Heat resistance of Bacillus larvae spores in beeswax medium was expressed by the index $\mathrm{D}_{150}{ }^{\circ} \mathrm{C}$, ranging from 1.5 -2.5 min depending on the initial concentration of spores. $0.5 \% \mathrm{H}_{2} \mathrm{SO}_{4}$ did not result in the reduction of the number of viable Bacillus larvae spores for the $37.5 \mathrm{~h}$ required for the isolation of spores from beeswax.
\end{abstract}

Bacillus larvae spore / beeswax / heat resistance / acid-resistance / disinfection

\section{INTRODUCTION}

Beeswax is an important bee product which returns partly into the hive in the form of comb foundations. When beeswax is processed at home or in smaller factories producing foundations, cleaning and disinfection usually necessitate $0.5 \%$ $\mathrm{H}_{2} \mathrm{SO}_{4}$ and a temperature of $80-90^{\circ} \mathrm{C}$ for $30 \mathrm{~min}$. This procedure is sufficient for liquidation of vegetative stages of bacteria. Vegetative cells of Bacillus larvae White are killed at a temperature of $60{ }^{\circ} \mathrm{C}$ in $15 \mathrm{~min}$ (Rose, 1969). This temperature does not destroy $B$ larvae spores; their heat resistance can even be increased utilising these temperatures (Gerhardt and Marquis, 1989).
The authors recommend a total temperature of $121^{\circ} \mathrm{C}$ at a pressure of $1 \mathrm{~atm}$ for 20-30 min to remove $B$ larvae spores from beeswax (Hornitzky and Wills, 1983; Shimanuki et al, 1984; Plessis et al, 1985).

Savov and Arsenov (1963) investigated the resistance of $B$ larvae spores to temperature without increased pressure and noted that dry heat destroys the spores at a temperature of $110^{\circ} \mathrm{C}$ in $2-3 \mathrm{~h}$, and at $140^{\circ} \mathrm{C}$ in $60-90 \mathrm{~min}$. A problem regarding the study of $B$ larvae in beeswax is that of their isolation from wax. Kostecki and Orlowski (1975) and Kostecki and Jeliński (1977) elaborated a method for determining $B$ larvae spores in wax using a solvent and subsequent centrifugation. Isolation of the spores from beeswax with subse- 
quent cultivation is likewise found in a study by Hansen and Rasmussen (1991).

The present contribution is aimed at preparing a routine method in order to determine the titre of $B$ larvae in beeswax, the survival of spores in $0.5 \%$ sulfuric acid and their heat resistance in wax medium at a constant temperature of $150^{\circ} \mathrm{C}$.

\section{MATERIALS AND METHODS}

\section{Choice of solvent}

Wax samples with added scale were dissolved in benzene, ether, chloroform and toluene. The following characteristics were examined visually: solubility of wax samples, formation of mist or sediment with solvent, removal of mist by replicated dissolving and centrifugation. The percentage of viable $B$ larvae spores trapped was determined by sample plating on MYPG medium. Evaluation also included a calculation involving the boiling points of different solvents, with benzene being selected.

\section{Method of isolation of B larvae spores from wax}

The study with infected wax involved the isolation of $B$ larvae spores from unsterile material according to the method of Rose (1969) and Wilson (1972). One $\mathrm{g}$ wax was dissolved in $9 \mathrm{ml}$ benzene. One $\mathrm{ml}$ dissolved wax was inoculated into $9 \mathrm{ml}$ standard nutritive broth. The same was incubated at $37^{\circ} \mathrm{C}$ for $12 \mathrm{~h}$ and later submitted to $70^{\circ} \mathrm{C}$ for $30 \mathrm{~min}$. Incubation and heating were replicated 3 times. Thus all nonsporulating microorganisms and vegetative cells germinated from spores capable of growing in nutritive broth were eliminated. The viability of $B$ larvae spores was determined by transferring of implantations $1 \mathrm{ml}$ of the sample prepared in this way on the MYPG sample (Dingman and Stahly, 1983). The inoculation was performed without further sample dilution. Grown colonies of $B$ lanvae were identified under the microscope and using the catalase test.

\section{Determination of viable $\mathrm{B}$ larvae spore concentration in wax}

\section{A) In scale dissolved in water medium}

The scale was weighed and standard nutritive broth added to the weight of $2 \mathrm{~g}$. After melting it was shaken in a shaker, diluted 10-fold with nutritive broth, incubated at a temperature of $37^{\circ} \mathrm{C}$ 3 times for $12 \mathrm{~h}$, and heat-treated after the above-mentioned procedure. Decadic dilution of samples in nutritive broth was plated on the MYPG medium. Five scales were processed in total. Average concentration of germinated spores of these samples was considered as $100 \%$.

\section{B) In a scale homogenized in wax and dissolved in benzene}

The scale was weighed and wax added to a weight of $1 \mathrm{~g}$. After mashing the scale in dissolved wax, $9 \mathrm{ml}$ benzene was added to the sample. The mixture was homogeneously shaken and the sample diluted with nutritive broth and incubated in the same manner, again heattreated and plated as A variant. In total 5 scales were treated in the same manner. By comparing results with those of $A$ variant, the sensitivity of the method applied was determined together with the percentage of germinated spores trapped on the wax

\section{Determination of heat resistance of B larvae spores in wax}

In experiments conducted for heat resistance, an initial number of spores was chosen as corresponding to 100 scales per comb of a frame measuring $39 \times 24 \mathrm{~cm}$. This spore quantity represents $\approx 3.10^{10}$ spores per $100 \mathrm{~g}$ of yielded wax, ie $3.10^{8}$ per $1 \mathrm{~g}$ wax. In the second case an accidental admixing of one slightly infected comb with 10 scales among 99 pure combs was considered. At a yield of $100 \mathrm{~g}$ wax per comb, $\approx$ $3.10^{9}$ spores should be expected in $10000 \mathrm{~g}$ of wax, ie $3.10^{5}$ per $1 \mathrm{~g}$ wax.

Samples prepared in this manner were distributed in 1-ml doses into test tubes with bacte- 
riological closure and placed in a hot-air drying kiln (laboratory type), heated to a temperature of $150{ }^{\circ} \mathrm{C}$ and kept at this temperature. When a temperature of $150{ }^{\circ} \mathrm{C}$ was reached, the samples were taken out at times $0,5,10,20,30$ and $60 \mathrm{~min}$. They were dissolved in $9 \mathrm{ml}$ benzene and the spore counts determined on the basis of the above-mentioned method. $D$ value was calculated by the formula: $\left(\log _{10} n_{0}-\log _{10} n\right) \times D=t_{n}$ (Ingram, 1969), where $n_{0}$ is an initial number of spores expressed in $\mathrm{g}$ and $n$ is the number of spores after $t$ min of heating at the given temperature.

\section{Determination of acid resistance of $\mathrm{B}$ larvae spores to $0.5 \% \mathrm{H}_{2} \mathrm{SO}_{4}$}

One $\mathrm{ml}$ of the wax sample containing scales with a spore concentration identical to that used in the experiments conducted for heat resistance was dissolved in $9 \mathrm{ml}$ benzene. One $\mathrm{ml}$ of this mixture was inoculated into $9 \mathrm{ml}$ standard nutritive broth with $0.5 \% \mathrm{H}_{2} \mathrm{SO}_{4}$. The sample was left in the medium containing $\mathrm{H}_{2} \mathrm{SO}_{4}$ for the entire incubation period with replicated heatings after this procedure, ie $37.5 \mathrm{~h}$. The concentration of spores was determined on the basis of variant $B$; see above.

\section{RESULTS AND DISCUSSION}

A method of $B$ larvae spore isolation from wax was tested and verified based on studies of Rose (1969) and Wilson (1972).

Of all solvents applied, benzene was found to be the best. Ether and chloroform, mixed with wax, combined to form a sediment which did not disappear even after repeated centrifugation and the use of the aforementioned solvents. After plating of this sample on the dish, a wax crust was formed in which the spores did not germinate. There was a reduction in the number of spores in replicated dissolution, sedimentation and decantation in the lower part of the jelly supernatant. Their low boil- ing point was found to be poor, this being $37^{\circ} \mathrm{C}$ for ether and $62^{\circ} \mathrm{C}$ for chloroform. An excessive growth of additional microflora in the Petri dishes was observed in an experiment with toluene. The method used in this study reliably destroys the additional microflora for the entire volume over the experimental period. There is no need for additional water, centrifugation and subsequent decantation of part of the volume (Kostecki and Jelinski, 1977), providing bacteriological and quantitative reliability to the above-mentioned process.

The sensitivity of the method was verified by determination of the number of $B$ larvae spores which germinated in the scale dissolved in water medium and the concentration of germinated $B$ larvae spores from the scale as contained in wax medium was compared with it. A value of $\approx 10^{9}$ cells is usually referred to in the literature for water medium for the concentration of spores in the scale. To this also corresponds the value (found by us) of the average number of $B$ larvae spores from 1 scale added to the water medium, ie $1.2 \mathrm{x}$ $10^{9}$. There were $2.7 \times 10^{8}$ spores from one scale applied in the wax. It was found that the method is not reliable within 1-10 spores in $1 \mathrm{~g}$ wax; but tens of spores contained in $1 \mathrm{~g}$ wax are unprovable. A low reduction of the titre of spores can be attributed to the long-term action of benzene which partly affects the viability of spores even with dilution in the nutritive broth. An unfavourable effect of benzene on spores is also referred to by Doyle and Ernst (1967). In spite of this, still after infected wax had been dissolved in benzene, for $72 \mathrm{~h}$ growing colonies of $B$ larvae were isolated in large numbers, though their concentration was not determined. The subsequent experiments were based on the results of determination of spore numbers contained in scale applied in the wax. 
Figures 1 and 2 show the results of these experiments regarding the determination of heat resistance of $B$ larvae at a constant temperature of $150{ }^{\circ} \mathrm{C}$. There was an exponential relation between the number of live spores and the time of treatment. This pattern is in accordance with the data as obtained by Ingram (1969). When logarithms were taken from the values giving the number of live spores - the $D$ value - the index of heat resistance of spores was calculated. $D$ value characterizes the decrease in live spores with time in lower order by 1 at a certain temperature in the given medium. $D_{150}{ }^{\circ} \mathrm{C}$ value for $B$ larvae spores as contained in wax ranged from 1.5-2.5 min after initial concentration of spores. One may see the tail (fig 1) disappear after calculating the logarithms of the values and incorporating

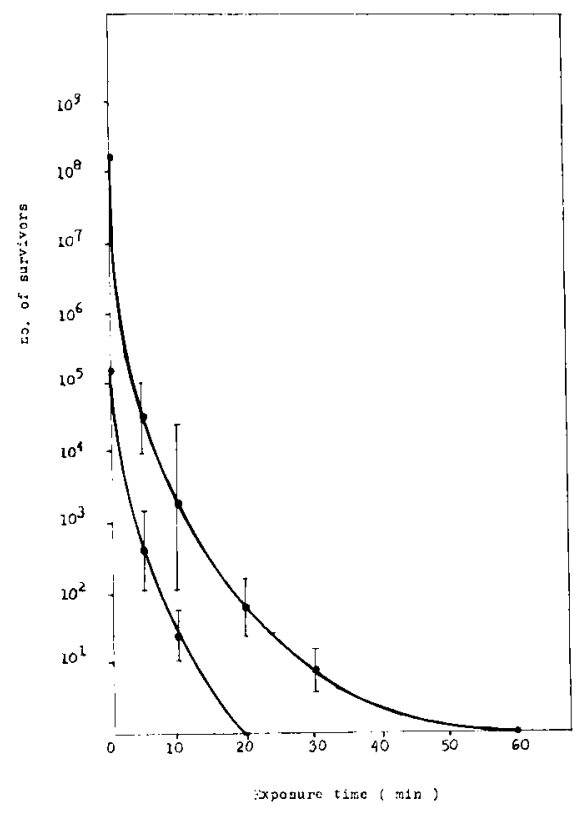

Fig 1. Actual survival count of 2 different concentrations $\left(3 \times 10^{8}\right.$ and $\left.3 \times 10^{5}\right)$ of Bacillus larvae spores heated in wax during exposure at $150^{\circ} \mathrm{C}$.

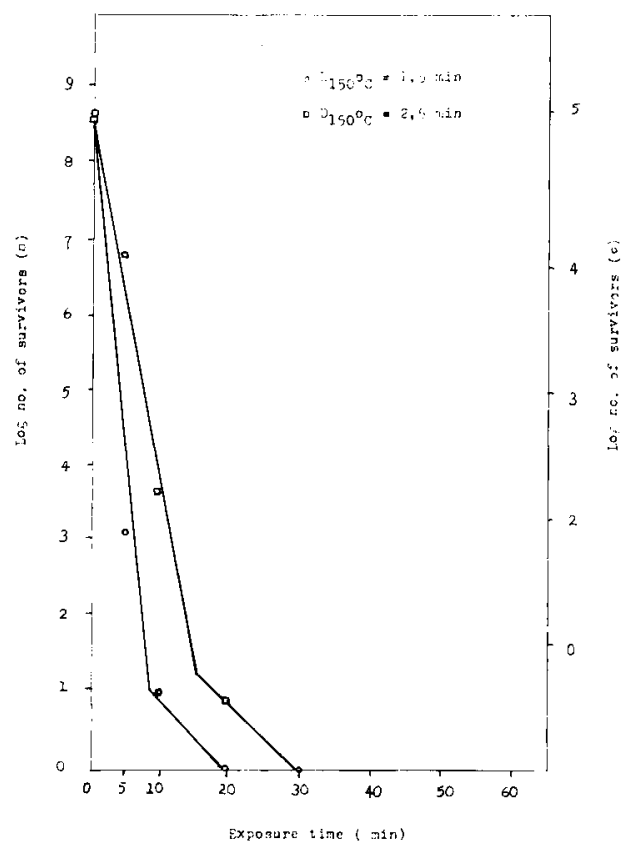

Fig 2. Decimal reduction rates ( $D$ values) of 2 different initial concentrations $\left(3 \times 10^{8}\right.$ and $3 \times$ $10^{5}$ ) of Bacillus larvae spores heated in wax during exposure at $150^{\circ} \mathrm{C}$.

these into the formula (fig 2). This tail is more apparent in particular when using high initial concentrations of spores and this probably means an expression of longer preservation of spores in the surrounding wax environment possibly due to the existence of heat-resistant mutants.

A certain role in heat resistance is played not only by genetic mechanisms (DNA multiple genomes) and the structure and the characteristic composition of spores, ie water, dipicolinic acid and metal contents (Soper and Davies, 1971; Gorman et al, 1984; Mallidis and Scholefield, 1985, 1986, 1987; Warth, 1985; Belliveau et al, 1990) but also by outer environment 
comprising spores. Fats of long carbon chains and of low water activity increase the heat resistance of spores, so-called fat protection (Roberts and Hitchins, 1969; Ingram, 1969; Lücke, 1985). Beeswax is considered as fat whose main proportion of components is formed by different esters, fatty acids and carbohydrates (Bacilek, 1987). For instance, $D_{95^{\circ} \mathrm{C}}$ value $=8 \mathrm{~min}$ for Bacillus megaterium in phosphate buffer and $D_{121}{ }^{\circ} \mathrm{C}$ value $=108 \mathrm{~min}$ in soybean oil (Molin and Snygg, 1967).

Acid resistance of spores is known (Roberts and Hitchins, 1969). $0.5 \% \mathrm{H}_{2} \mathrm{SO}_{4}$ did not reduce the number of live Bacillus larvae spores in wax for $37.5 \mathrm{~h}$ in our experiments. This was required for isolation of spores from wax. $0.5 \% \mathrm{H}_{2} \mathrm{SO}_{4}$ plays a role in the purification of wax (Vesely et al, 1985 ), but plays no role in the disinfection of wax. It follows from the experiments that the time needed for sterilization of infected wax at a temperature of $150{ }^{\circ} \mathrm{C}$ is dependent on the number of spores present in the wax. An hour can be considered as the maximum time in which $99.9 \%$ of all spores were inactivated from an initial high concentration of $3.10^{8}$ in $1 \mathrm{~g}$ wax. After a shorter period of time a temperature of $150{ }^{\circ} \mathrm{C}$ results in physical and chemical changes in beeswax. The lower temperatures are tested for wax sterilization for this reason. It seems that the use of lower temperatures should be compensated by longer exposure time if sterilization is to be successful.

\section{Résumé - Résistance de Bacillus lar-} vae dans le cire d'abeille. L'augmentation de la résistance des spores à la chaleur en présence de corps gras (fat protection) est un fait bien connu (Molin et Snygg, 1967) et on peut s'attendre à une influence semblable de la cire d'abeilles sur la survie des spores de Bacillus larvae. Les spores de $B$ larvae ont été isolées à partir de cire non stérile d'après les méthodes de Rose (1969) et de Wilson (1972). La cire infectée a été dissoute dans le benzène dans la proportion de $1: 9$, puis inoculée dans un bouillon de culture dans la même proportion. Dans le cas de la détermination de la résistance à l'acide, $0,5 \%$ d'acide sulfurique a été ajouté. Par la méthode du chauffage et de l'incubation répétés, on a éliminé des matériaux testés tous les microorganismes non sporulants et tous les micro-organismes sporulants moins exigeants pour leur croissance. Les spores survivantes ont été inoculées sur milieu MYPG. Pour étudier la thermorésistance des spores de $B$ larvae, la cire infectée a été exposée à la température constante de $150^{\circ} \mathrm{C}$ pendant des durées variant de 5 à $60 \mathrm{~min}$ (fig 1). La thermorésistance a été exprimée par l'indice $D_{150}{ }^{\circ} \mathrm{C}$ qui variait en fonction de la concentration initiale des spores : de 1,5 à 2,5 min pour des concentrations respectives de $3 \times 10^{5}$ et $3 \times 10^{8} / \mathrm{g}$ de cire (fig 2). À des concentrations initiales plus élevées, on obtient un tracé plus allongé (présence d'une "queue» de courbe) dû aux spores qui survivent plus longtemps. L'acide sulfurique à la concentration de $0,5 \%$ n'a pas réduit le nombre de spores survivantes pendant tout le temps nécessaire à leur isolement $(37,5 \mathrm{~h})$. Des essais sont actuellement en cours pour stériliser la cire à des températures plus basses, la température de $150{ }^{\circ} \mathrm{C}$ induisant des modifications physico-chimiques de la cire d'abeille.

Bacillus larvae / spore / résistance à la chaleur / résistance à l'acide / cire d'abeille / désinfection

\section{Zusammenfassung - Die Resistenz von Bacillus larvae im Bienenwachs. Bei den Sporen von Bacillus larvae ist ein "Fettschutz" (fat protection) bekannt (Molin und Snygg, 1967); es kann deshalb ein}


ähnlicher Einfluß des Bienenwachses auf die Sporen angenommen werden. Bei der Untersuchung der Thermoresistenz der Sporen von Bacillus larvae wurde das verseuchte Wachs für unterschiedliche Zeit einer konstanten Temperatur ausgesetzt; nachher wurde es in Benzen im Verhältnis 1:9 gelöst und in eine Nährbouillon geimpft, die im Falle der Prüfung der Säureresistenz mit $\mathrm{H}_{2} \mathrm{SO}_{4}$ (auf eine Konzentration von $0,5 \%$ ) ergänzt wurde. Durch Anwendung der Methode der wiederholten Erwärmung und Kultur zur Isolierung von Sporen von Bacillus larvae aus dem nicht sterilisierten Material nach Wilson (1972) oder nach Rose (1969) wurden aus dem geprüften Material alle nicht sporulierenden Mikroorganismen und alle weniger anspruchsvollen sporulierenden Keime entfernt. Die überlebenden Sporen wurden auf ein MYPG-Medium geimpft.

Die Thermoresistenz der Sporen von Bacillus larvae im Bienenwachs bei einer Temperatur von $150^{\circ} \mathrm{C}$ wurde durch den Index $D_{150}{ }^{\circ} \mathrm{C}$ ausgedrückt, der sich in $\mathrm{Ab}$ hängigkeit von der Anfangskonzentration der Sporen innerhalb des. Bereiches von 1,5 bis 2,5 min bewegte (Abb 1). Bei einer höheren Anfangskonzentration der Sporen findet man auf dem Diagramm einen länger ausgezogenen Verlauf ("Kurvenschwanz"), der durch länger überlebende Sporen gebildet wird. Die Beifügung von $\mathrm{H}_{2} \mathrm{SO}_{4} \mathrm{zu}$ einer Konzentration von $0,5 \%$ in der Lösung verringerte während der ganzen, für die Isolation erforderlichen Zeit (37,5 Stunden) die Zahl der lebenden Bacillus larvae-Sporen nicht.

Diese Resultate wurden bei praktischen Prüfungen der Wachsdesinfektion mittels Temperaturen von über $100{ }^{\circ} \mathrm{C}$ unter Beachtung der Wachsqualität angewandt.

\section{Bacillus larvae (Sporen) / Bienen- wachs / Hitzeresistenz / Säureresistenz / Desinfektion}

\section{REFERENCES}

Bacilek J (1987) Vliv zpracování na kvalitu včelího vosku. Věd Práce Vúvč v Dole p 7-20

Belliveau DH, Beaman TC, Gerhardt P (1990) Heat resistance correlated with DNA content in Bacillus megaterium spores. Appl Environ Microbiol 56 (9), 2919-2921

Dingman DW, Stahly DP (1983) Medium promoting sporulation of Bacillus farvae and metabolism of medium components. Appl Environ Microbiol 46, 860-869

Doyle JE, Ernst RR (1967) Resistance of Bacillus subtilis var niger spores occluded in water-insoluble crystals to three sterilization agents. Appl Microbiol 15, 726-730

Gerhardt P, Marquis RE (1989) Spore thermoresistance mechanisms. In: Regulation of Procaryotic Development (Smith I, Slepecky RA, Setlow P, eds) Am Soc Microbiol, Washington, 43-64

Gorman SP, Scott EM, Hutchinson EP (1984) Emergence and development of resistance to antimicrobial chemicals and heat in spores of Bacillus subtilis. J Appl Bacteriol 51, 153-163

Hansen H, Rasmussen B (1991) Empfindlichkeit des Faulbrutbakteriums Bacillus larvae gegenüber Hitzebehandlung. Die Biene (3), 129-131

Hornitzky MAZ, Wills PA (1983) Gamma radiation inactivation of Bacillus larvae to control American foulbrood. J Apic Res 22 (3), 196199

Ingram M (1969) Sporeformers as food spoilage organisms. In: The Bacterial Spore (Gould GW, Hurst A, eds) Academic Press, London, 549-610

Javornik $F$ (1989) Huda gniloba čebelje zalege. Slovenski Cebelar 91 (2), 45-47

Kostecki R, Jelinski M (1977) Investigations on the sterilization of beewax for foundation production. Bull Vet Inst Pulawy 21 (1-2), 6-9

Kostecki R, Orlowski J (1975) Ausspülen von Bacillus-larvae-Sporen aus dem für Mittelwände bestimmten Wachs. In: $X X V$ Int Bienenzüchterkongr. Apimondia, Bucharest, $402-403$

Lücke FK (1985) Heat inactivation and injury of Clostridium botulinum spores in sausage mix- 
tures. In: Fundamental and Applied Aspects of Bacterial Spores (Dring GF-J, Ellar DJ, Gould GW, eds) Academic Press, London 409-420

Mallidis CG, Scholefield J (1985) Determination of the heat resistance spores using a solid heating block system. J Appl Bacteriol 59, 407-411

Mallidis CG. Scholefiekd J (1986) Relation to the heat resistance of bacterial spores to chemical composition and structure I. Relation to core components. J Appl Bacteriol 62 , 65-69

Mallidis CG, Scholefield J (1987) Relation of the heat resistance of bacterial spores to chemical composition and structure II. Relation to cortex and structure. J Appl Bacteriol 63, 207-215

Molin N, Snygg BG (1967) Effect of lipid material on heat resistance of bacterial spores. App/ Microbiol 15, 1422-1426

Orlowski J (1968) Mozliwosc przenoszenia zgnilcow za posrednictwem wosku i wezy. Pszczelarstwo 8, 8-9

Plessis TA, Du-Rensbrug HJ, Van-Johannsmeier MF (1985) The gamma sterilization of beewax. S Afr Bee J 57 (3), 54-57

Roberts TA, Hitchins AD (1969) Resistance of spores. In: The Bacterial Spore (Gould GW,
Hurst A, eds) Academic Press, London, 612670

Rose RI (1969) Bacillus larvae, isolation, culturing and vegetative thermal death point. $J / n$ vertebr Pathol 14 (3), 411-414

Savov D, Arsenov L (1963) Dejstvijeto na njakom chimicni i fizicni sredstva srescu amerikanskaja gnilec. IzV Veterin Int Zarazni Parazit Bolezsti 8, 195-200

Shimanuki H, Herbert EW Jr, Knox DA (1984) High velocity electron beams for bee disease control. Am Bee J 124, 865-867

Soper CJ, Davies DJG (1971) The effect of high vacuum drying on the beat response of Bacillus megaterium spores. In: Spore Research 1971 (Barker AN, Gould GW, Wolf J, eds) Academic Press, London, 275-288

Veselý V (1985) Včelarství. SZN, Prague, 328336

Warth AD (1985) Mechanism of heat resistance. In: Fundamental and Applied Aspects of Bacterial Spores (Dring GH, Ellar DJ, Gould GW, eds) Academic Press, London, 209-225

Wilson WT (1972) Resistance to American foulbrood in honey bees. XII. Persistence of viable Bacillus larvae spores in the feces of adults permitted flight. $J$ Invertebr Pathol 20 (2), 165-169 